\title{
Colour, phenolic content and antioxidant activity of grape juice
}

\author{
Cor, conteúdo fenólico e atividade antioxidante de sucos de uva
}

\author{
Vívian Maria BURIN ${ }^{1}$, Leila Denise FALCÃO ${ }^{1}$, Luciano Valdemiro GONZAGA ${ }^{1}$, \\ Roseane FETT ${ }^{1}$, Jean Pierre ROSIER ${ }^{2}$, Marilde Terezinha BORDIGNON-LUIZ ${ }^{1 *}$
}

\begin{abstract}
Viticultural practices in the State of Santa Catarina, Brazil, have shown economic growth, with the production of grapes used to produce wines and grape juice. Grapes are rich in phenolic compounds which have drawn attention not only because of their important role in the development of products derived from grapes, but also for their potential beneficial health effects. The objective of this study was to evaluate commercial, organic and homemade grape juices produced in Santa Catarina. Grape juices were analyzed for total phenolic content, colour, and antioxidant activity. The commercial juices had the highest average values for total monomeric anthocyanins and total phenolics. There was a strong positive correlation $(\mathrm{R}=0.9566)$ between the antioxidant activity and total phenolic content for the commercial juice. In addition, the Principle Components Analysis showed a strong positive correlation between the red colour and total monomeric anthocyanins. However, the total monomeric anthocyanis and polymeric anthocyanins showed a negative correlation.

Keywords: anthocyanins; phenolics compounds; Vitis labrusca.
\end{abstract}

\section{Resumo}

As práticas vitícolas mostram crescimento econômico no Estado de Santa Catarina, com produção de uvas que são utilizadas para produzir vinhos e sucos. As uvas são ricas em compostos fenólicos e têm chamado a atenção não somente devido ao importante papel no desenvolvimento de produtos derivados de uvas, mas também por seu potencial efeito benéfico para a saúde. O objetivo deste trabalho foi avaliar sucos de uva comercial, orgânico e artesanal produzidos no Estado de Santa Catarina. Os sucos de uvas foram analisados quanto ao conteúdo de polifenol total, coloração e atividade antioxidante. Os sucos comerciais tiveram os maiores valores médios de antocianinas monoméricas totais e de polifenóis totais. Foi obtida ótima correlação $(R=0,9566)$ entre a atividade antioxidante e o conteúdo de polifenóis totais nos sucos comerciais. A Análise de Componentes Principais (ACP) mostrou haver forte correlação entre a cor vermelha e as antocianinas monoméricas totais. No entanto, entre as antocianinas monoméricas e as poliméricas ocorreu correlação negativa.

Palavras-chave: antocianinas; compostos fenólicos; Vitis labrusca.

\section{Introduction}

Phenolic compounds are widely distributed in the plant kingdom. They are found in many foods in different concentrations (SCALBERT; WILLIAMSON, 2000). In grapes, they are present in the pulp, skin, and seeds. They are considered one of the most important quality parameters of grapes and their products since they contribute to their colour and organoleptic characteristics such as flavour, bitterness, and astringency. Phenolic compounds are also effective antioxidants (DANGLES; WIGAND; BROUILLARD, 1992; GÓMEZ-CORDOVÉS; GONZÁLEZ-SANJOSÉ, 1995).

Grapes, and in particular red grape products, are rich in phenolic compounds (FULEKI; RICARDO-DA-SILVA, 2003). Phenolic compounds have drawn attention not only because of their important role in the development of grape products, but also for their beneficial health effects (O'BYRNE et al., 2002; BUB et al., 2003). They have antioxidant properties and can prevent the oxidative damage of cells (CAVALLINI;
BINDOLI; SILIPRANDI, 1978; LOPEZ-VELEZ; MARTÍNEZMARTÍNEZ; DEL VALLE-RIBES, 2003; PARK et al., 2003). Several epidemiological and clinical studies have reported the benefits of consuming fruits and vegetables high in polyphenols, resulting in reduced risks of developing cardiovascular diseases and several types of cancers (GARCÍA-ALONZO et al., 2004). Polyphenols are multifunctional, and their antioxidant activity may be due to their ability to act as reducing agents by donating hydrogen, capturing singlet oxygen (HANASAKI; OGAWA.; FUKUI, 1994; LUGASI; HÓVARI, 2003), or acting as chelators (BUB et al., 2003).

The effect of consuming food and beverages rich in polyphenols in terms of preventing diseases such as cancer and coronary diseases (LAPIDOT et al., 1999; LAZZÉ et al., 2003) is quite significant. Polyphenols can also reduce damage to DNA and production of free radicals in the body (BUB et al., 2003). Many of the flavonoids found in grape juice, such as catechin,

Recebido para publicação em 2/12/2008

Aceito para publicação em 29/6/2009 (003971)

Programa de Pós-graduação de Ciência dos Alimentos, Departamento de Ciência e Tecnologia de Alimentos, Rod. Admar Gonzaga, n. 1346, CEP 88034-001,

Itacorubi, Florianópolis - SC, Brasil, E-mail: bordign@cca.ufsc.br

${ }^{2}$ Empresa de Pesquisa e Extensão Agropecuária de Santa Catarina, Estação Experimental, Videira - SC, Brasil

${ }^{*}$ A quem a correspondência deve ser enviada 
epicatechin, quercetin, and anthocyanins are known to have antioxidant, anti-inflammatory, and platelet inhibitory effects, as well as for being able to reduce LDL oxidation and oxidative damage to DNA, both in vitro and in animal studies (FRANKEL et al., 1998; SINGLETARY et al., 2003).

Colour is the most important attribute used, along with other variables, as an indicator of the quality of grape juice. This characteristic is directly dependent on the phenolic composition of the juice and the anthocyanins present in the grape skin (MAZZA; MINIATI, 1993). The anthocyanins participate in many reactions that promote changes in the colour of grape products, mainly through copigmentation and formation of polymeric pigments (WROLSTAD; DURST; LEE, 2005).

The quantity and composition of phenolic compounds and anthocyanins differ according to the species, variety, maturity of the grapes, weather, viticultural practices, and the region where the grapes are grown (MAZZA, 1995; BAUTISTAORTÍN et al., 2007). Different methods and treatments used during the production of grape juice also affect significantly the final phenolic composition, compared to that in natura fruit. These include the type of extraction and contact time, as well as heat and enzymatic treatments (FRANKEL et al., 1998). The high temperatures used during the extraction, storage, and pasteurization led to the degradation of anthocyanins and, consequently, a decrease in the colour and total phenolics content (MORRIS; SISTRUNK; SIMS, 1986).

The objective of this study was to evaluate the total phenolic content, colour, and antioxidant activity of commercial, organic, and homemade grape juices produced in the State of Santa Catarina.

\section{Materials and methods}

\subsection{Grape juice samples}

The analysis was carried out on 12 grape juice samples produced in the State of Santa Catarina, Brazil, comprising 7 commercial juices (C), 2 organic grape juices (CO), and 3 homemade grape juices (A). All juices were manufactured with Bôrdo grapes (Vitis labrusca) in the months of February and March 2007. All reagents were of analytical grade. All analyses were performed in triplicate, and the results were expressed as means \pm S.D.

\subsection{Analytical determinations}

\section{Physical-chemical analysis}

The samples of grape juice were analyzed for soluble solids content $\left({ }^{\circ} \mathrm{Brix}\right), \mathrm{pH}$, titratable acidity measurements (g tartaric acid. $\mathrm{L}^{-1}$ ), and total solids (\%) according to Amerine and Ough (1976).

\section{Determination of total phenols}

The amounts of total phenols in the grape juices were determined according to the Folin-Ciocalteu colorimetric method (SINGLETON; ROSSI, 1965), and the results were expressed as gallic acid equivalent (mgGAE.L $\left.{ }^{-1}\right)$.

\section{Determination of total monomeric anthocyanins}

The total anthocyanins were determined by the $\mathrm{pH}$ differential method described by Giusti and Wrolstad (2001). For this purpose, aliquots of the juices were adjusted to $\mathrm{pH}$ 1.0 and 4.5 with buffers. The absorbance of each solution was measured at wavelength of maximum absorption and $700 \mathrm{~nm}$. The difference in the absorbance values $\mathrm{pH} 1.0$ and 4.5 was directly proportional to total anthocyanin concentration, which was expressed in malvidin 3.5-diglucoside. $\mathrm{L}^{-1}$.

\section{Antioxidant capacity}

The antiradical activities of the grape juices were determined using the stable 1,1-diphenyl-2-picrylhydrazyl radical (DPPH) according to Kim, Guo and Packer (2002) with modifications. A sample of $100 \mu \mathrm{M}$ of DPPH was dissolved in $80 \%$ aqueous methanol. The samples $(0.1 \mathrm{~mL})$ were added to $2.9 \mathrm{~mL}$ of methanol $\mathrm{DPPH}^{*}$ solution. The decrease in the absorbance of the resulting solution was monitored at $517 \mathrm{~nm}$ for 30 minutes. The $\mathrm{DPPH}^{\bullet}$ radical scavenging activity of the grape juice was expressed as Trolox Equivalent Antioxidant Capacity (TEAC) $(\mathrm{mM})$.

\section{Colour measurements}

a) Monomeric and polymeric anthocyanins: the contribution of monomeric anthocyanins to the grape juice colour at $\mathrm{pH} 3.6$ (\% monomeric), and the degree of anthocyanin polymerization (\% polymerization) were determined using the colorimetric effects that $\mathrm{SO}_{2}$ and acetaldehyde have in the forms of anthocyanins, following the method proposed by Levengood and Boulton (2004). The analysis was conducted by spectrophotometry, and the absorbance $(520 \mathrm{~nm})$ was measured in a $1 \mathrm{~mm}$ cuvette. The reading was corrected by multiplying by 10. Colour fractions of the monomeric (MA\%) and polymerized anthocyanins (PA\%) were determined through the following calculations (Equations 1 and 2):

$\mathrm{MA} \%=\left(\mathrm{A}^{20}-\mathrm{A}^{\mathrm{SO} 2}\right) / \mathrm{A}^{\text {acet }} \times 100$

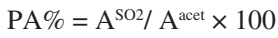

b) Colour Intensity (CI), Tint (T): CI and $\mathrm{T}$ were determined using the spectrophotometric absorbance of the grape juices at 420, 520, $620 \mathrm{~nm}$ (GLORIES, 1984), and the following calculations (Equations 3 and 4):

$\mathrm{CI}=$ Abs $420+$ Abs $520+$ Abs 620

$\mathrm{T}=\operatorname{Abs} 420 /$ Abs 520

\section{Statistical analysis}

Analysis of variance (ANOVA), Principal Components Analysis (PCA), and correlation analysis were conducted using Statistica 6.0 (2001) (StatSoft Inc., Tulsa, OK, USA). 


\section{Results and discussion}

\section{Physico-chemical analysis}

The results for the physico-chemical analysis of the grape juices are shown in Table 1. The commercial grape juice samples had higher mean values for total acidity than those of homemade grape juice. For the ${ }^{\circ}$ Brix and TS values, the homemade grape juice had the highest values indicating that these juices contain a greater amount of solids.

Brazilian Legislation (BRASIL, 2000) requires that grape juices have a minimum of $14{ }^{\circ}$ Brix, however, some juices presented lower values (Table 1). Regarding total acidity, the same legislation establishes a minimum value of 0.41 . In this case, all samples were in accordance with the legislation.

The ${ }^{\circ}$ Brix/total acidity represents the balance between the acid and sweet taste of grape juice, and thus, it indicates the quality of the grape juice. Brazilian Legislation establishes limit values between 15 and 45 . The high ${ }^{\circ}$ Brix/total acidity values obtained may be due to the low acidity of the grape juices.

\section{Total monomeric anthocyanins}

The determination of total anthocyanins was performed by the $\mathrm{pH}$-differential method, and the results are shown in Table 2. There was a significant difference $(\mathrm{p}<0.05)$ between the samples of the same type of juice. It was observed that anthocyanin values ranged from 25.56 to $460 \mathrm{mg} . \mathrm{L}^{-1}$ for the commercial sample (C4) and homemade grape juice sample (A3), respectively.

The determinant factors in the variation of anthocyanin concentration in grape juices are the techniques used in the juice processing, such as high temperatures during the extraction and pasteurization, as well as the different forms of storage (FRANKEL et al., 1998). Grape juices may be packed in transparent bottles and exposed to the light, which affects the phenolic content, especially in the anthocyanins, which could lead to a reduction in its colouring level (MORRIS; SISTRUNK; SIMS, 1986).

Malacrida and Motta (2005) determined total anthocyanins in commercial grape juice. The anthocyanin mean values were $28.7 \mathrm{mg} . \mathrm{L}^{-1}$ (juice) and $17.3 \mathrm{mg} . \mathrm{L}^{-1}$ (reconstitute juice), that is, around ten times lower than those found in our study. This difference may be due to the type of grape used, the juice processing, and storage methods. The temperature used during the processing and storage of juices can cause changes in the colour of the product. This is due to the formation of chalcones (colourless) causing loss of colour due to anthocyanin degradation (JACKMAN; SMITH, 1996).

Research studies carried out with Italian wines produced from different varieties of the grape Vitis vinifera $(n=7)$ have shown that total anthocyanin levels ranged from 102 to $405 \mathrm{mg} . \mathrm{L}^{-1}$ (CIMINO et al., 2007). Munõz-Espada et al. (2004) quantified the level of total anthocyanin monomers by the $\mathrm{pH}$-differential method in wines manufactured with three non-Vitis vinifera grapes (Marechal Foch, Norton, and Concord varieties). Concord wine showed a mean value of $170 \mathrm{mg} . \mathrm{L}^{-1}$ and Marechal Foch wine of 140 mg. $\mathrm{L}^{-1}$. Comparing the total anthocyanin levels reported for grape juice samples, the values were found to be close to, although higher than, those found in the wine samples.

\section{Total Phenolics (TP)}

The Total Phenolic content (TP) ranged from 3433.04 to $1117.10 \mathrm{mg} \mathrm{GAE} . \mathrm{L}^{-1}$ in the commercial juice samples C2 and $\mathrm{C} 1$, respectively, as shown in Table 2. All commercial juice samples showed significant differences $(\mathrm{p}<0.05)$, which was not observed for the organic juices. This statistical difference between the grape juices could be due to differences in the juice processing techniques, such as extraction type, time and temperature, and the addition, or not, of enzymes, as well as other factors related to the grapes, such as the grape maturity and cultivation practices.

Table 1. Physicochemical analysis of grape juice samples.

\begin{tabular}{cccccc}
\hline Juices $^{\star *}$ & $\mathrm{pH}^{\star}$ & $\begin{array}{c}\text { TSS } \\
\left({ }^{\circ} \text { Brix }\right)^{\star}\end{array}$ & $\begin{array}{c}\text { Titratable } \\
\text { acidity }\end{array}$ & $\begin{array}{c}\text { Total solids } \\
(\mathrm{g} \%)^{\star}\end{array}$ & $\begin{array}{c}\text { TSS/titratable } \\
\text { acidity }(\mathrm{g} \%)^{*}\end{array}$ \\
\hline $\mathrm{A} 1$ & $3.30^{\mathrm{a}}$ & $10.0^{\mathrm{a}}$ & $8.20 \pm 0.09^{\mathrm{a}}$ & $12.03 \pm 0.23^{\mathrm{a}}$ & 12.1 \\
$\mathrm{~A} 2$ & $3.51^{\mathrm{a}}$ & $19.0^{\mathrm{b}}$ & $6.87 \pm 0.09^{\mathrm{b}}$ & $24.55 \pm 0.09^{\mathrm{b}}$ & 27.1 \\
$\mathrm{~A} 3$ & $3.64^{\mathrm{a}}$ & $21.5^{\mathrm{c}}$ & $6.44 \pm 0.08^{\mathrm{c}}$ & $33.87 \pm 1.6^{\mathrm{c}}$ & 33.4 \\
$\mathrm{C} 1$ & $3.30^{\mathrm{a}}$ & $15.5^{\mathrm{ad}}$ & $9.84 \pm 0.15^{\mathrm{a}}$ & $14.51 \pm 0.09^{\mathrm{a}}$ & 15.8 \\
$\mathrm{C} 2$ & $3.56^{\mathrm{b}}$ & $12.0^{\mathrm{b}}$ & $7.35 \pm 0.09^{\mathrm{b}}$ & $11.86 \pm 0.03^{\mathrm{b}}$ & 16.3 \\
$\mathrm{C} 3$ & $3.34^{\mathrm{c}}$ & $9.5^{\mathrm{c}}$ & $8.62 \pm 0.08^{\mathrm{c}}$ & $12.59 \pm 0.09^{\mathrm{c}}$ & 11.0 \\
$\mathrm{C} 4$ & $3.51^{\mathrm{b}}$ & $14.5^{\mathrm{a}}$ & $7.72 \pm 0.09^{\mathrm{d}}$ & $14.40 \pm 0.04^{\mathrm{a}}$ & 18.7 \\
$\mathrm{C} 5$ & $3.43^{\mathrm{c}}$ & $16.0^{\mathrm{d}}$ & $5.60 \pm 0.07^{\mathrm{e}}$ & $17.15 \pm 0.27^{\mathrm{d}}$ & 28.6 \\
$\mathrm{C} 6$ & $3.42^{\mathrm{c}}$ & $15.5^{\mathrm{ad}}$ & $9.25 \pm 0.09 \mathrm{f}$ & $15.5 \pm 0.13^{\mathrm{e}}$ & 16.7 \\
$\mathrm{C} 7$ & $3.25^{\mathrm{d}}$ & $12.5^{\mathrm{b}}$ & $9.41 \pm 0.08 \mathrm{f}$ & $11.64 \pm 0.29^{\mathrm{b}}$ & 13.3 \\
$\mathrm{CO} 1$ & $3.40^{\mathrm{a}}$ & $15.0^{\mathrm{a}}$ & $9.63 \pm 0.10^{\mathrm{a}}$ & $14.66 \pm 0.06^{\mathrm{a}}$ & 15.6 \\
$\mathrm{CO} 2$ & $3.32^{\mathrm{b}}$ & $12.0^{\mathrm{b}}$ & $8.03 \pm 0.09^{\mathrm{b}}$ & $11.18 \pm 0.21^{\mathrm{b}}$ & 14.9 \\
\hline
\end{tabular}

**homemade grape juice $(\mathrm{A})$; commercial grape juice $(\mathrm{C})$, and organic grape juice $(\mathrm{CO})$; ${ }^{*}$ Mean values for triplicates \pm S.D. Different letters in the same column are significantly different at the $5 \%$ level (Tukey HSD Test). TSS, total Soluble Solids ( ${ }^{\circ}$ Brix); Titratable acidity (g tartaric acid. $\left.\mathrm{L}^{-1}\right)$; and total solids ( $\mathrm{g} \%$ ).

Table 2. Determination of Total Anthocyanins (TA), Total Polyphenols (TP) and Antioxidant Activity (DPPH) of homemade (A), Commercial (C) and organic (CO) grape juices.

\begin{tabular}{lrcr}
\hline Juices & TA $\left(\mathrm{mg} \cdot \mathrm{L}^{-1}\right)^{\star}$ & TP $\left(\mathrm{mg} \cdot \mathrm{L}^{-1}\right)^{\star}$ & DPPH $(\mathrm{mM})^{\star}$ \\
\hline A1 & $241.22 \pm 0.15^{\mathrm{a}}$ & $2509.06 \pm 18.26^{\mathrm{a}}$ & $8.23 \pm 0.17^{\mathrm{a}}$ \\
A2 & $207.99 \pm 2.94^{\mathrm{b}}$ & $21374.56 \pm 23.21^{\mathrm{b}}$ & $7.32 \pm 0.48^{\mathrm{a}}$ \\
A3 & $460.45 \pm 10.01^{\mathrm{c}}$ & $235.09 \pm 10.13^{\mathrm{b}}$ & $7.94 \pm 0.45^{\mathrm{a}}$ \\
C1 & $42.45 \pm 0.33^{\mathrm{a}}$ & $1117.10 \pm 4.38^{\mathrm{a}}$ & $2.51 \pm 0.03^{\mathrm{a}}$ \\
C2 & $336.31 \pm 1.38^{\mathrm{b}}$ & $3433.04 \pm 4.988^{\mathrm{b}}$ & $11.05 \pm 0.13^{\mathrm{b}}$ \\
C3 & $431.11 \pm 1.55^{\mathrm{c}}$ & $3228.36 \pm 18.26^{\mathrm{c}}$ & $9.57 \pm 0.17^{\mathrm{c}}$ \\
C4 & $25.56 \pm 0.86^{\mathrm{d}}$ & $1257.60 \pm 41.45^{\mathrm{d}}$ & $5.53 \pm 0.11^{\mathrm{d}}$ \\
C5 & $124.95 \pm 1.12^{\mathrm{e}}$ & $2286.82 \pm 57.52^{\mathrm{e}}$ & $7.26 \pm 0.16^{\mathrm{e}}$ \\
C6 & $79.99 \pm 1.77^{\mathrm{f}}$ & $1737.13 \pm 10.13^{\mathrm{f}}$ & $6.22 \pm 0.59^{\mathrm{f}}$ \\
C7 & $307.73 \pm 2.50^{\mathrm{g}}$ & $2918.42 \pm 17.54^{\mathrm{g}}$ & $9.22 \pm 0.21^{\mathrm{c}}$ \\
CO1 & $221.51 \pm 3.09^{\mathrm{a}}$ & $2634.79 \pm 26.79^{\mathrm{a}}$ & $8.24 \pm 0.19^{\mathrm{a}}$ \\
CO2 & $168.50 \pm 1.80^{\mathrm{b}}$ & $2643.57 \pm 41.45^{\mathrm{a}}$ & $9.08 \pm 0.16^{\mathrm{b}}$ \\
\hline
\end{tabular}

${ }^{*}$ Mean values for triplicates \pm S.D. Different letters in the same column are significantly different at the $5 \%$ level (Tukey HSD Test); TA (mg malvidin 3.5 diglucoside. $\mathrm{L}^{-1}$ ); TP (mg GAE.L-1); DPPH (Expressed as Trolox Equivalent Antioxidant Capacity (TEAC) $(\mathrm{mM})$ ). 
The total polyphenol contents have also been compared in studies carried out with different juice types produced from white and red grapes obtained through conventional or organic agricultural methods. It was observed that the red grape juices had higher phenolic contents than those of white grape juices, and organic juices had higher phenolic contents than those of juices made from conventionally farmed grapes (DANI et al., 2007). In this study, the mean TP values in the organic juice

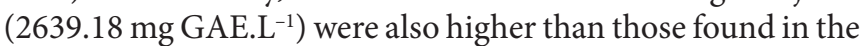
commercial juice (2282.64 mg GAE. $\mathrm{L}^{-1}$ ). In similar studies on TP content in grape juices using the Folin-Ciocalteu method carried out by Frankel et al. (1998), the results for Concord grape juice ranged between 1654 - $1971 \mathrm{mg} \mathrm{GAE} . \mathrm{L}^{-1}$; and for juices produced with a greater variety of grapes, the TP range was 1407-1541 mg GAE.L ${ }^{-1}$. The same authors mention that the phenolic contents of grape juice may be influenced by the procedures employed in the juice production and reactions occurring during storage.

Cabernet Sauvignon wines (Vitis vinifera) of the 2004 and 2005 vintages from four different places in Santa Catarina State were analyzed for the total phenolic contents, showing TP values ranging from 1.008 to $1.597 \mathrm{mg} \mathrm{GAE.L^{-1 }}$ (FALCÃO et al., 2007). These values are lower than the grape juice samples analyzed in this study, also originating from Santa Catarina State. This shows that grape juice can be considered as a source of phenolic compounds without being alcoholic.

In the technological context, the profile of the phenolic composition of grapes represents a determinant factor in wine and grape juice quality. This profile can also be used to monitor the production process and in the quality control of those beverages.

\section{Scavenging capacity}

The antioxidant capacity evaluated using the DPPH method ranged from 2.51 to $11.05 \mathrm{mM}$ (Table 2) for all juices. No significant differences between the samples of homemade juice $(\mathrm{p}<0.05)$ were observed; however, in the commercial juice samples differences occurred.

In studies carried out with wine made from non-Vitis vinifera grapes, Munõz-Espada et al. (2004) showed that the average antioxidant activity values were $0.85 \mathrm{mM}$, which are lower than those found in the grape juice study here reported. In another study, the antioxidant activity was determined by the DPPH method in sixteen samples of red wine, and it was observed that the values ranged from 6.10 to $17.41 \mathrm{mM}$ (FERNÁNDEZ-PANCHÓN et al., 2004). These results are closer to those obtained for the samples of grape juice here reported.

Vinson, Teufel and $\mathrm{Wu}$ (2001) carried out a study comparing the action of red wine, dealcoholized wine, and red grape juice in relation to atherosclerosis inhibition in hamsters. They demonstrated that all tested beverages produced significant inhibition of atherosclerosis. However, when comparing the inhibition effect of the three samples, all with the same polyphenol concentration, the grape juice yielded the best result. These data suggest that grape juice is an excellent alternative to red wine for people who need to avoid alcoholic beverages.
It is known that the antioxidant activity of grape products is influenced by its phenolic composition (DÁVALOS; BARTOLOMÉ; GÓMEZ-CORDOVÉS, 2005). In order to investigate the contribution of phenolic constituents to the antioxidant activity in grape juices, a linear regression was obtained between the DPPH values, Total Phenolic content (TP), and Total Anthocyanin (TA) in commercial juices. Higher correlations were found between TP content and DPPH $(\mathrm{R}=0.9566)$ when compared with TA and DPPH $(\mathrm{R}=0.8307)$. This is also shown in Figure 1, in which the mathematical model proved well adjusted for polyphenol total and antioxidant capacity. In a study with sixteen samples of red wine correlating antioxidant activity (DPPH) and phenolic content (TP), the correlation coefficient of 0.8237 was reported (FERNÁNDEZ-PACHÓN et al., 2004), which is less than the values obtained with grape juice.

Dani et al. (2007), researching different red grape juices, also observed a positive correlation between the total phenolic content (Folin-Ciocalteu) and the antioxidant activity (DPPH). The same authors have shown that for grape juices made from Vitis labrusca grapes, considered an antioxidant source, the biological activity is influenced not only by the phenolic levels, but also by the agricultural method utilized.

\section{Grape juice colour}

The results for the colour characterization of the homemade (A), commercial (C), and organic (CO) grape juices are represented in Table 3.

Most commercial juices and all of the homemade juice samples showed significant differences $(\mathrm{p}<0.05)$ for monomeric and polymeric anthocyanins, with higher percentages of monomeric anthocyanins. Their contribution to the coloration of commercial juices ranged from 35.71 to $69.48 \%$; however, the highest percentages were observed in homemade grape (76.39\%). The polymeric anthocyanins, present in all juices, showed mean values ranging from 31.73 to $65.71 \%$. Malacrida and Motta (2005) have reported that an average grape juice value of $81.6 \%$ for polymeric anthocyanins is related to juice colour.

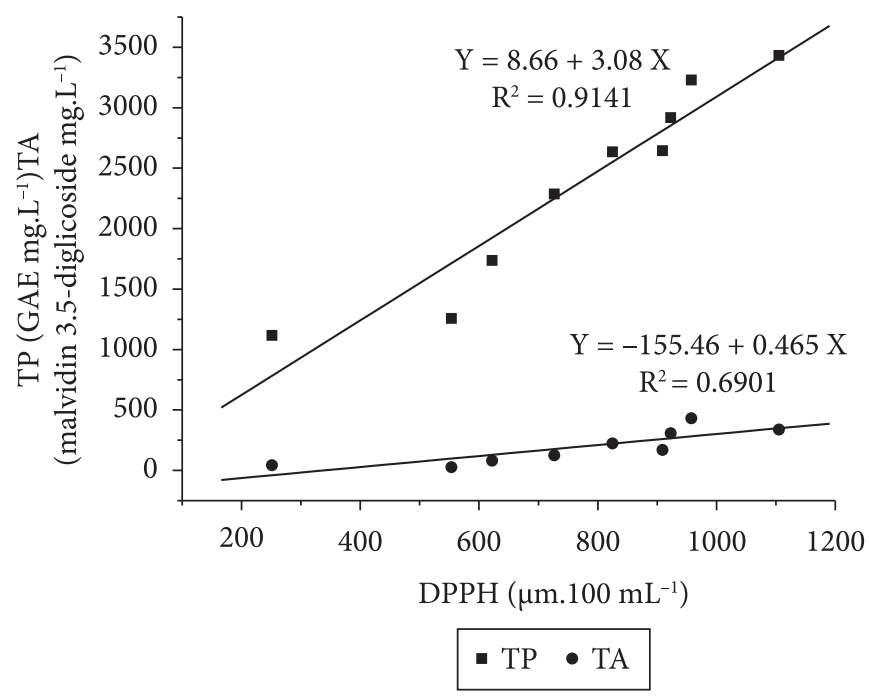

Figure 1. Interaction between Total Phenolics (TP) and antioxidant activity $(\mathrm{DPPH})$ in Commercial $(\mathrm{C})$ and organic $(\mathrm{CO})$ grape juice samples. 


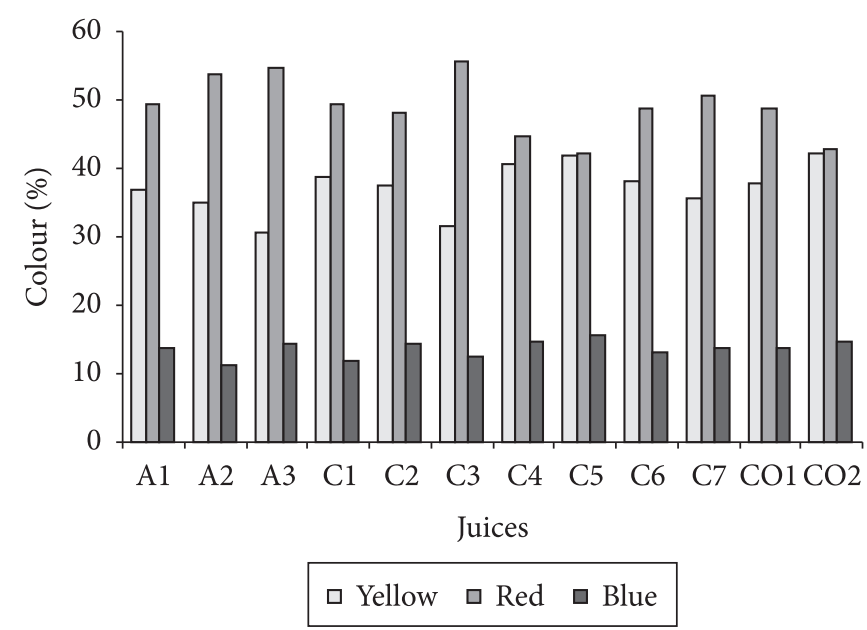

Figure 2. Representation of colour (yellow, red, and blue) in homemade (A), commercial (C), and organic (CO) juices.

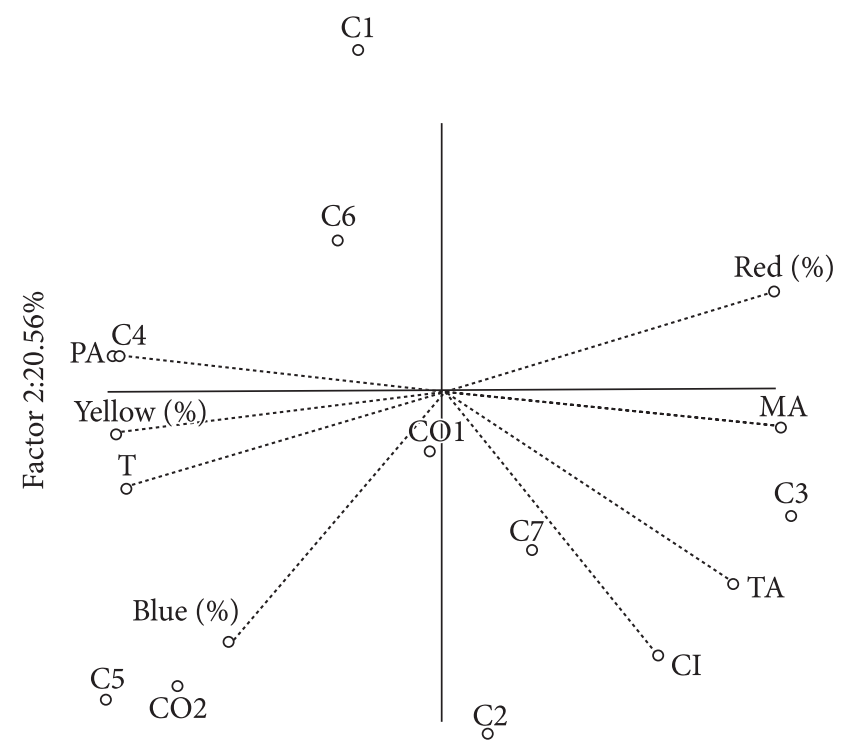

Factor 1:76.30\%

Figure 3. Principal Components Analysis (PCA) of grape juice colour parameters.

Table 3. Characterization of grape juice colour.

\begin{tabular}{|c|c|c|c|c|}
\hline Juice ${ }^{\star *}$ & $\mathrm{CI}^{*}$ & $\mathrm{~T}^{*}$ & $\mathrm{PA}(\%)^{*}$ & $\operatorname{MA}(\%)^{*}$ \\
\hline A1 & $16.32 \pm 0.01^{\mathrm{a}}$ & $0.75 \pm 0.01^{\mathrm{a}}$ & $44.15 \pm 0.01^{\mathrm{a}}$ & $57.33 \pm 0.01^{\mathrm{a}}$ \\
\hline A2 & $8.16 \pm 0.01^{b}$ & $0.65 \pm 0.01^{\mathrm{b}}$ & $31.73 \pm 0.01^{\mathrm{b}}$ & $76.39 \pm 0.01^{\mathrm{b}}$ \\
\hline A3 & $16.62 \pm 0.02^{c}$ & $0.56 \pm 0.02^{c}$ & $25.9 \pm 0.04^{c}$ & $66.7 \pm 0.04^{c}$ \\
\hline $\mathrm{C} 1$ & $5.37 \pm 0.02^{\mathrm{a}}$ & $0.78 \pm 0.02^{\mathrm{ab}}$ & $51.06 \pm 0.04^{\mathrm{a}}$ & $50.2 \pm 0.04^{\mathrm{ab}}$ \\
\hline $\mathrm{C} 2$ & $20.58 \pm 0.01^{b}$ & $0.78 \pm 0.01^{\mathrm{bf}}$ & $42.7 \pm 0.02^{\mathrm{b}}$ & $58.4 \pm 0.03^{c}$ \\
\hline $\mathrm{C} 3$ & $21.12 \pm 0.02^{c}$ & $0.57 \pm 0.03^{c}$ & $31.54 \pm 0.01^{\mathrm{c}}$ & $69.48 \pm 0.01^{\mathrm{d}}$ \\
\hline $\mathrm{C} 4$ & $6.72 \pm 0.01^{\mathrm{d}}$ & $0.91 \pm 0.02^{\mathrm{d}}$ & $65.71 \pm 0.02^{\mathrm{d}}$ & $35.71 \pm 0.02^{\mathrm{a}}$ \\
\hline C5 & $12.68 \pm 0.01^{\mathrm{e}}$ & $1.04 \pm 0.01^{\mathrm{e}}$ & $60.42 \pm 0.01^{\mathrm{e}}$ & $42.55 \pm 0.51^{\mathrm{bd}}$ \\
\hline C6 & $9.31 \pm 0.01^{\mathrm{f}}$ & $0.76 \pm 0.02^{\mathrm{af}}$ & $54.6 \pm 0.01^{\mathrm{f}}$ & $46.13 \pm 0.01^{\mathrm{d}}$ \\
\hline C7 & $18.34 \pm 0.02^{\mathrm{g}}$ & $0.70 \pm 0.02^{\mathrm{a}}$ & $44.27 \pm 0.02^{\mathrm{g}}$ & $55.12 \pm 0.02^{\mathrm{e}}$ \\
\hline $\mathrm{CO} 1$ & $13.11 \pm 0.02^{\mathrm{a}}$ & $0.77 \pm 0.01^{\mathrm{a}}$ & $46.85 \pm 0.02^{\mathrm{a}}$ & $55.02 \pm 0.01^{\mathrm{a}}$ \\
\hline $\mathrm{CO} 2$ & $16.81 \pm 0.01^{\mathrm{b}}$ & $0.98 \pm 0.01^{\mathrm{b}}$ & $59.82 \pm 0.01^{\mathrm{b}}$ & $40.33 \pm 0.01^{\mathrm{b}}$ \\
\hline
\end{tabular}

During the juice processing stages and, particularly, during their storage, the anthocyanin content decreased progressive and irreversibly forming more stable polymeric pigments. These pigments are responsible for changing the grape juice aroma, colour, and flavour (FRANCIA-ARICHA et al., 1997).

The commercial juice samples showed a significant difference $(\mathrm{p}<0.05)$ regarding Colour Intensity $(\mathrm{CI})$. The CI represents the amount of colour present in the juices. The CI values ranged from 5.37 to 21.12 .

Figure 2 shows the percentage of yellow, red, and blue colour for commercial, homemade, and organic grape juices. All juices showed a higher percentage of red colour, followed by yellow and blue. These data are correlated with the results for the tint (T) of the juice samples, being inversely proportional (Table 3 ).

Principal Components Analysis (PCA) (Figure 3) was conducted on the correlation matrix using all commercial grape juice ( $\mathrm{C}$ and $\mathrm{CO}$ ) colour attributes. Figure 3 shows that the juices were clearly separated by two factors, with the axes of Factor $1 \times$ Factor 2 explaining $96.47 \%$ of the total variance among the data. The first axis represents $76.27 \%$ and the second axis $20.76 \%$ of the total dispersion.

Figure 3 shows that the monomeric anthocyanins, total anthocyanins (mg.L $\mathrm{L}^{-1}$ ), and red color (\%) are negatively correlated with Factor 1, in which the monomeric anthocyanins and red color (\%) were both strongly correlated. It was also observed that the values for Polymeric Anthocyanins (PA), Tint (T), and yellow colour percentage were strongly positively correlated with Factor 1. With regard to Factor 2, the percentage of blue colour and Colour Intensity (CI) were negatively correlated with this factor. It can be observed that the red colour was negatively correlated with $\mathrm{T}$, and that monomeric was negatively correlated with polymeric anthocyanin.

For the commercial juices, samples $\mathrm{C} 5$ and $\mathrm{CO} 2$ showed higher correlations with blue colour and T. Samples C7 and C2 were correlated with total anthocyanins and colour intensity, and sample C3 indicated a strong correlation with monomeric anthocyanins.

\section{Conclusions}

In the grape juice samples high concentrations of total anthocyanins and polyphenols content were observed, values similar to those reported for red wine.

The content of total phenols, total monomeric anthocyanins, and antioxidant activity differed significantly among the commercial juice samples.

A strong correlation was observed between the antioxidant activity and phenolic content in the commercial grape juice samples, which indicates that grape juice is a source of these compounds providing an alternative option for people who need to avoid alcohol.

The results suggest that the total polyphenol of grape juice can be used to determine the characteristics of this product, and that it can also be used as a parameter for monitoring the productive process, or even for studies on quality control. 


\section{References}

AMERINE, M. A.; OUGH, C. S. Analisis de vinos y mostos. Zaragoza: Acribia, 1976. p. 19-35.

BAUTISTA-ORTÍN, A. B. et al. The effects of enological practices in anthocyanins, phenolic compounds and wine colour and their dependence on grape characteristics. Journal of Food Composition and Analysis, v. 20, p. 546-552, 2007.

BRASIL. Instrução Normativa $n^{\circ} 01$, de 07 de junho de 2000. Aprova o regulamento técnico para fixação dos padrões de identidade e qualidade para polpa de fruta. Diário Oficial [da] República Federativa do Brasil, Poder Executivo, Brasília, DF, 10 jan. 2000.

BUB, A. et al. Fruit juice consumption modulates antioxidative status, immune status, and DNA damage. Journal of Nutrition Biochemistry, v. 14, p. 90-98, 2003.

CAVALLINI, L.; BINDOLI, A.; SILIPRANDI, N. Comparative evaluation of antiperoxidative action of flavonoids. Pharmacological Research Communications, v. 10, p. 133-136, 1978.

CIMINO, F. et al. Radical-scavenging capacity of several Italian red wines. Food Chemistry, v. 103, p. 75-81, 2007.

DANGLES, O.; WIGAND M. C.; BROUILLARD, R. Anthocyanin anticopigment effect. Phytochemistry, v. 31, p. 3811-3812, 1992.

DANI, C. et al. Phenolic content and antioxidant activities of white and purple juice manufactured with organically - or conventionallyproduced grapes. Food and Chemical Toxicology, v. 45, p. 25742580, 2007.

DÁVAlOS, A.; BARTOLOMÉ, B.; GÓMEZ-CORDOVÉS, C. Antioxidant properties of commercial grape juice and vinegars. Food Chemistry, v. 93, p. 325-330, 2005.

FALCÃO, L. D. et al. Relation between scavenging properties with total polyphenol, anthocyanins content and color characteristics in Cabernet Sauvignon wines. In: SYMPOSIUM INTERNATIONAL D'OENOLOGIE DE BORDEAUX, 8., p. 234, 2007.

FERNÁNDEZ-PACHÓN, M. S. et al. Antioxidant activity of wines and relation with their polyphenolic composition. Analytica Chimica Acta, v. 513, p. 113-118, 2004.

FRANCIA-ARICHA, E. M. et al. New Anthocyanins Pigments Formed after Condensation with Flavanols. Journal of Agriculture and Food Chemistry, v. 45, p. 2262-2266, 1997.

FRANKEL, E. N. et al. Commercial grape juices inhibit the in vitro oxidation of human low-density lipoproteins. Journal of Agriculture and Food Chemistry, v. 46, p. 834-838, 1998.

FULEKI, T.; RICARDO-DA-SILVA, M. J. Effects of cultivar and processing method on the contents of catechins and procyanidins in grape juice. Journal of Agriculture and Food Chemistry, v. 51, p. 640-646, 2003.

GARCÍA-ALONSO, M. et al. Evaluation of the antioxidante properties of fruits. Food Chemistry, v. 84, p.13-18, 2004.

GIUSTI M. M.; WROLSTAD, R. E. Characterization and measurement of anthocyanins by UV-Visible spectroscopy. In: WROLSTAD, R. E. (Ed.). Current protocols in food analytical chemistry. New York: John Wiley \& Sons, 2001. Unit F1.2.

GLORIES, Y. La couleur des vins rouges. 2ème partie mesure, origine et interpretation. Connaissance de la Vigne et du Vin, v. 18, p. 253-271, 1984.

GOMEZ-CORDOVES, M. C.; GONZÁLEZ-SANJOSÉ, M. L. Interpretation of color variables during the aging of red wines: relationship with families of phenolic compounds. Journal of Agriculture and Food Chemistry, v. 43, p. 557-561, 1995.

HANASAKI, Y.; OGAWA, S.; FUKUI, S. The correlation between active oxygens scavenging and antioxidative effects of flavonoids. Free Radical Biology and Medicine, v. 16, p. 845-850, 1994.
JACKMAN, R. L.; SMITH, J. L. Anthocyanins and betalains. In: HENDRY, G. A. F.; HOUGHTON, J. D. (Eds.). Natural Food Colorants. 2. ed. Londres: Chapman \& Hall, 1996. p. 245-309.

KIM, Y. K.; GUO, Q.; PACKER, L. Free radical scavenging activity of red ginseng aqueous extracts. Toxicology, v. 172, p. 149-156, 2002.

LAPIDOT, T. et al. $\mathrm{pH}$-dependent forms of red wine anthocyanins as antioxidants. Journal of Agriculture and Food Chemistry, v. 47, p. 67-70, 1999.

LAZZÉ, M. C. et al. Anthocyanins protect against DNA damage induced by tert-butyl-hydroperoxide in rat smooth muscle and hepatoma cells. Mutation Research, v. 513, p. 103-115, 2003.

LEVENGOOD, J.; BOULTON, R. The variation in the color due to copigmentation in young cabernet sauvignon wines. In: WATERHOUSE, A. L. ; KENNEDY, J.A. (Ed.). Red Wine Color. Washington: American Chemical Society, 2004. 314 p.

LOPEZ-VELEZ, M.; MARTÍNEZ-MARTÍNEZ, F.; DEL VALLE-RIBES, C. The study of phenolic compounds as natural antioxidants in wine - critical reviews. Food Science and Nutrition, v. 43, p. 233-244, 2003.

LUGASI, A.; HÓVARI, J. Antioxidant properties of commercial alcoholic and nonalcoholic beverages. Nahrung/Food, v. 47, p. 79-86, 2003.

MALACRIDA, C. R.; MOTTA, S. Compostos fenólicos totais e antocianinas em suco de uva. Ciência e Tecnologia de Alimentos, v. 25, p. 659-664, 2005.

MAZZA, G. Anthocyanins in grape and grape products. Critical Review of Food Science and Nutrition, v. 35, p. 341-371, 1995.

MAZZA, G.; MINIATI, E. Anthocyanins in fruits, vegetables and grains. Boca Raton: CRC, 1993.

MORRIS, J. R.; SISTRUNK, W. A.; SIMS, C. A. Effects of fruit maturity, juice storage, and juice extraction temperature on quality of 'Concord' grape juice. Journal of the American Society for Horticultural Science, v. 111, p. 742-746, 1986.

MUNÕZ-ESPADA, A. C. et al. Anthocyanin quantification and radical scavenging capacity of concord, Norton, and Marechal Foch grapes and wines. Journal of Agriculture and Food Chemistry, v. 52, p. 6779-6786, 2004.

O'BYRNE, D. et al. Comparison of the antioxidant effects of Concord grape juice flavonoids and R-tocopherol on markers of oxidative stress in healthy adults. American Journal of Clinical Nutrition, v. 76, p. 1367-1374, 2002.

PARK, Y. K. et al.Daily grape juice consumption reduces oxidative DNA damage and plasma free radical levels in healthy Koreans. Mutation Research, v. 529, p. 77-86, 2003.

SCALBERT, A.; WILLIAMSON, G. Dietary intake and bioavailability of polyphenols. American Society for Nutritional Sciences, v. 130, p. 2073S-2085S, 2000.

SINGLETARY, K. W. et al. Inhibition of mammary Tumorigenesis by concord grape juice constituents. Journal of Agriculture and Food Chemistry, v. 51, p. 7280-7286, 2003.

SINGLETON, V. L.; ROSSI, J. A. Colourimetry of total phenolics with phosphomolibdicphosphotungstic acid reagent. American Journal of Enology and Viticulture, v. 16, p. 144-158, 1965.

VINSON, J. A.; TEUFEL, K.; WU, N. Red wine, dealcoholized red wine, and especially grape juice, inhibit atheroclerosis in a hamster model. Atherosclerosis, v. 156, p. 67-72, 2001.

WROLSTAD, R. E.; DURST, R. W.; LEE, J. Tracking color and changes in anthocyanin products. Trends in Food Science \& Technology, v. 16, p. 423-428, 2005. 